\title{
Case Based Reasoning Diagnosis Penyakit Cardiovascular Dengan Metode Simple Matching Coefficient Similarity
}

\author{
Edi Faizal ${ }^{1}$ \\ ${ }^{1}$ Teknik Komputer STMIK El Rahma Yogyakarta \\ Email: ${ }^{1}$ edsoftku@gmail.com
}

(Naskah masuk: 11 Juni 2014, diterima untuk diterbitkan: 22 Juli 2014)

\begin{abstract}
Abstrak
Penyakit kardiovaskuler atau cardiovascular disease (CVD) menurut definisi WHO adalah istilah bagi serangkaian gangguan jantung dan pembuluh darah. Data badan kesehatan dunia WHO (2012) menunjukan bahwa CVD adalah faktor penyebab kematian nomor satu didunia dan berdasarkan data Riset Kesehatan Dasar (RISKESDAS) Kementerian Kesehatan Republik Indonesia tahun 2007 menunjukkan, penyakit yang termasuk kelompok CVD menempati urutan teratas penyebab kematian di Indonesia. Ditinjau dari sisi ketersediaan tenaga ahli dibidang cardiovascular, saat ini Indonesia hanya memiliki sekitar 500 dokter spesialis penyakit jantung dan pembuluh darah. Artinya dengan jumlah penduduk Indonesia yang mencapai 240 juta, rasio dokter spesialis jantung dan pembuluh darah adalah 1:480.000 penduduk. Jumlah ini masih sangat kurang dibandingkan dengan kebutuhan penduduk di Indonesia. Rasio yang diharapkan adalah 1:250.000 penduduk. Penelitian ini menerapkan case-based reasoning untuk membangun sebuah sistem yang memiliki kemampuan untuk mendiagnosa penyakit cardiovascular berdasarkan kemiripan (similaritas) pada kasus-kasus terdahulu mengunakan metode simple matching coefficient similarity. Hasil pengujian menunjukan bahwa sistem yang dibangun memiliki nilai sensitifitas 97,06\%, spesifisitas 64,29\%, PPV 86,84\%, NPV 90,00\%, akurasi 87,50\% dengan tingkat kesalahan (error rate) sebesar 12,50\%.
\end{abstract}

Kata kunci: cardiovascular, case based reasoning, simple matching coefficient

\begin{abstract}
Cardiovascular disease (CVD) according to the WHO definition is the term for a series of heart and blood vessel disorders. World Health Organization (2012) showed that CVD is the factor number one cause of death in the world and based on data from the Health Research (RISKESDAS) Ministry of Health of the Republic of Indonesia in 2007 showed, diseases including CVD group occupy the top cause of death in Indonesia. In terms of the availability of experts in the field of cardiovascular, Indonesia currently only have around 500 specialist heart and blood vessel disease (SpJP). This means that the number of Indonesian population reached 240 million, the ratio of specialist is 1:480.000 population. This amount is very less compared to the needs of the population in Indonesia. Expected ratio is 1:250,000 population. This study will apply a case -based reasoning to build a system that has the ability to diagnose cardiovascular disease based on the similarity in the previous cases using method of simple matching coefficient. Test results the system showed of sensitivity value $97,06 \%$, specificity of $64,29 \%, P P V \quad 86,84 \%, N P V 90,00 \%$ and accuracy of $87,50 \%$ with an error rate of $12,50 \%$.
\end{abstract}

Keywords: cardiovascular, case-based reasoning, simple matching coefficient

\section{PENDAHULUAN}

Perkembangan teknologi begitu pesat terutama dalam bidang komputer, sehingga tidak berlebihan apabila komputer dijadikan alat untuk memperingan beban kerja manusia. Semakin berkembangnya teknologi menyebabkan makin banyak pekerjaan yang memerlukan keahlian tertentu. Menciptakan tenaga ahli (human expert) memerlukan waktu yang relatif lama serta biaya yang tidak sedikit. Salah satu usaha alternatif untuk menanggulangi kebutuhan ini adalah dengan menciptakan suatu sistem cerdas berbasis komputer.

Pengkajian dan penelitian untuk mewujudkan harapan tersebut dilakukan dengan meniru sistem kecerdasan manusia untuk menghasilkan sebuah sistem komputer yang mampu berfikir seperti seorang manusia yang dikenal dengan istilah kecerdasan buatan (artificial intelligence). Salah satu implementasi dari cabang kecerdasan buatan yang cukup terkenal adalah sistem pakar (expert system). Mengingat sulitnya proses akuisisi pengetahuan maka para ahli komputer mencoba mempelajari metode lain penyelesaian masalah dikenal dengan penalaran berbasis kasus (case-based reasoning).

Representasi pengetahuan (knowledge representation) dari sebuah case-based reasoning/CBR adalah berupa kumpulan kasus (case base) yang pernah terjadi sebelumnya. CBR menggunakan solusi dari kasus terdahulu yang mirip 
dengan kasus saat ini untuk menyelesaikan permasalahan. Metode yang dapat digunakan dalam menghitung kemiripan (similarity) adalah Simple Matching Coefficient.

Jika kasus baru mempunyai kemiripan dengan kasus lama, maka CBR akan menggunakan kembali (reuse) solusi kasus lama sebagai rekomendasi solusi kasus baru tersebut. Tetapi jika tidak ada yang cocok maka CBR akan melakukan adaptasi, dengan cara memasukkan/menyimpan (retain) kasus baru tersebut ke dalam database kasus, sehingga secara tidak langsung pengetahuan CBR akan bertambah. Semakin banyak kasus yang tersimpan dalam basis kasus, maka akan semakin cerdas pula sistem CBR tersebut.

Kardiovaskuler (cardiovascular disease/CVD) adalah istilah bagi serangkaian gangguan jantung dan pembuluh darah. Data badan kesehatan dunia WHO tahun 2012 menunjukan bahwa CVD adalah faktor penyebab kematian nomor satu didunia. Pada tahun 2008 terdapat 17,3 juta orang meninggal akibat CVD, angka ini mewakili 30\% dari penyebab kematian dunia. 7,3 juta kematian terjadi karena jantung koroner dan 6,2 juta akibat stroke.

Berdasarkan data RISKESDAS tahun 2007, penyakit yang termasuk kelompok CVD menempati urutan teratas penyebab kematian di Indonesia yaitu sebanyak 31,9\%. Hasil Survai Kesehatan Daerah tahun 2010 menunjukkan bahwa propinsi DIY masuk dalam lima besar provinsi dengan kasus hipertensi terbanyak.

Kualitas dan peningkatan akses pelayanan penyakit CVD sangat bergantung pada ketersediaan dan distribusi dokter spesialis. Saat ini, Indonesia memiliki sekitar 500 dokter spesialis penyakit jantung dan pembuluh darah. Jumlah ini masih sangat kurang dibandingkan dengan kebutuhan penduduk di Indonesia yang mencapai 240 juta. Rasio yang diharapkan adalah 1:250.000 penduduk.

Berdasarkan fakta-fakta di atas maka perlu dibuat sebuah sistem yang mampu mendiagnosa penyakit cardiovascular. Sistem yang dibangun merupakan implementasi dari penalaran berbasis kasus, dimana dengan CBR pemecahan kasus baru dilakukan dengan mengadapatasi solusi dari kasuskasus lama yang sudah terjadi (Pal\& Shiu, 2004). Sistem menerima input berbetuk biner (1 dan 0) diamana, nilai 1 menunjukan adanya gejala atau faktor resiko dan nilai 0 menunjukan tidak ada gejala atau faktor resiko dalam sebuah kasus. Perhitungan kedekatan (similarity) antara kasus baru dan kasus lama menggunakan metode simple mathcing coefficient yang merupakan salah satu teknik perhitungan kemiripan data biner.

Beberapa penelitian dalam domain penyakit kardiovakuler yang telah dilakukan antara lain, penelitian yang dilakukan ( Febrianti dkk, 2007) dengan menganalisis JST RPROP untuk mengenali pola elektrokardiografi dalam mendeteksi penyakit jantung koroner dengan akurasi $100 \%$ untuk data latih dan 84.21\% untuk data uji. Effendy dkk (2008), memprediksi penyakit jantung koroner menggunakan JST backpropagation. Hasil pengujian menunjukan metode JST-BP dapat mengenali pola-pola faktor risiko penyakit jantung koroner sebesar $80 \%$.

Abbas (2012) menggunakan konsep poly tree terstruktur dan model directed acyclic graphical (DAG) untuk memprediksi semua kasus yang dapat menyebabkan penyakit jantung koroner dan ditahun yang sama Shekar dkk (2012) mengusulkan sebuah algoritma baru untuk memprediksi penyakit jantung menggunakan teknik CBR. Sistem diimplementasi menggunakan bahasa Java dan berhasil melakukan prediksi tingkat resiko yang berbeda pada serangan jantung secara efektif.

Penerapan CBR dalam bidang penyakit kardiovakuler dilakukan Salem dkk (2005) dengan membangun prototype case-based expert system diagnosis penyakit jantung. Sementara Tomar dkk (2012) menggunakan CBR dalam membangun multimedia sistem pendukung keputusan (MMDSS) diagnosis penyakit jantung Salem dkk (2005) menggunakan 110 kasus untuk 4 jenis penyakit jantung. Dua metode retrieval yang digunakan yaitu metode induksi dan nearest-neighbor. Sedangkan Tomar dkk (2012) menggunakan 315 kasus untuk 4 penyakit jantung. Metode retrieval yang digunakan adalah nearest-neighbor.

Penelitian Tursina (2012) menerapkan casebased reasoning untuk diagnosa penyakit respirologi anak dengan similaritas simple mathcing coefficient untuk 250 kasus. Threshold 0.95 sebagai indikator apakah kasus baru akan di-retain ke basis kasus atau tidak. Pengujian dengan dua cara yaitu dengan dan tanpa threshold. Pengujian tanpa threshold menunjukan tingkat akurasi sebesar $89 \%$. Sedangkan dengan menggunakan variasi threshold $0,5,0,75$ dan 0,95 diperoleh hasil masing-masing $100 \%, 12,67 \%$ dan $0,67 \%$.

\section{PERANCANGAN SISTEM}

Sistem yang dibangun digunakan untuk melakukan diagnosa awal penyakit jantung dan pembuluh darah (cardiovascular) dengan menerapkan metode case-based reasoning. Teknik pencocokan antara kasus lama dan kasus baru menggunakan simple matching coefficient. Pada dasarnya, CBR merupakan salah satu metode yang menggunakan solusi kasus sebelumnya untuk menyelesaikan kasus yang baru.

Masukan sistem berupa faktor resiko (risk factor) dan data gejala-gejala (symtoms) penyakit yang dialami pasien, kemudian data tersebut dibuat menjadi kasus. Terdapat dua jenis kasus, yaitu target case dan source case. Source case merupakan datadata kasus yang dimasukkan ke dalam sistem yang berfungsi sebagai pengetahuan bagi sistem. Sedangkan target case merupakan data kasus baru yang akan dicari solusinya. 
Proses diagnosa kasus baru dilakukan dengan cara memasukkan data pasien, faktor resiko dan gejala-gejala yang dialami pasien pada kasus baru. Kasus baru tersebut kemudian diproses dengan cara menghitung similaritas atau kesamaan dengan kasus-kasus sebelumnya yang tersimpan dalam basis kasus. Kesamaan masing-masing faktor resiko dan gejala akan dihitung menggunakan persamaan (1).

Hasil perhitungan pada masing-masing kasus akan diurutkan dari nilai tertinggi ke nilai tererndah. Nilai yang paling tinggi adalah kasus yang paling mirip dengan kasus baru. Nilai kemiripan antara 0 samapai dengan 1 (dalam bentuk persentase antara
0\% sampai dengan 100\%). Jika nilai kemiripan sama dengan 1, maka kasus lama tersebut sama persis dengan kasus baru, dan sebaliknya semakin kecil nilai similaritasnya maka semakin tidak mirip kasus tersebut. Apabila nilai tersebut lebih kecil dari nilai ambang (threshold) yang ditentukan yaitu 0.8 (Campos dkk, 2010), maka solusi dari kasus stersebut harus di resvisi terlebih dahulu oleh pakar. Hasil keluaran (output) dari sistem adalah berupa nama penyakit dan solusi yang paling mirip dengan kasus saat ini. Secara umum arsitektur sistem CBR terlihat pada Gambar 1.

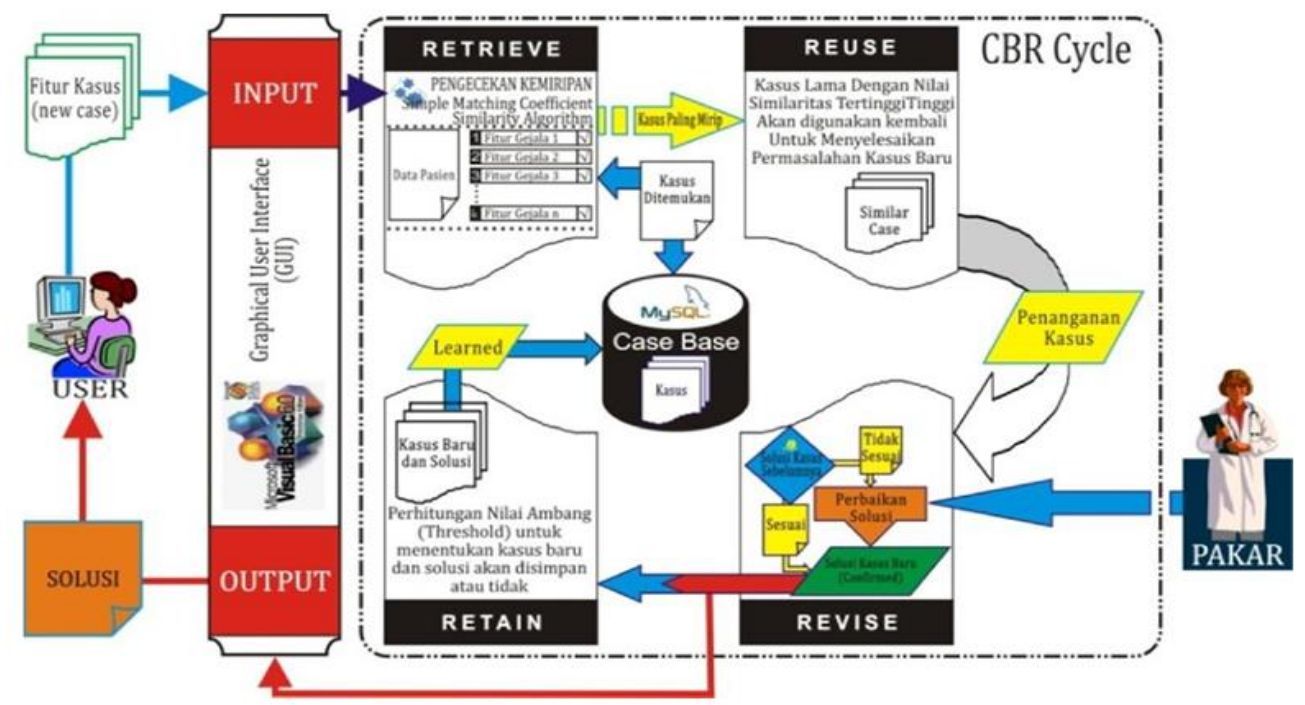

Gambar 1. Arsitektur Sistem

\subsection{Akuisisi Pengetahuan}

Case base akan dibentuk dari kumpulan data rekam medis pasien rawat inap penyakit kardiovaskuler. Tahap berikutnya adalah melakukan akuisisi pengetahuan yaitu proses untuk mengumpulkan data-data pengetahuan dari sumber pengetahuan. Sumber pengetahuan tersebut dijadikan sebagai informasi untuk dipelajari, diolah dan diorganisasikan secara terstruktur menjadi basis pengetahuan. Sumber pengetahuan diperoleh dari seorang pakar (dokter spesialis penyakit jantung dan pembuluh darah/SpJP). Selain pakar, bahan pengetahuan ini juga diperoleh dari literatur-literatur yang berkaitan dengan masalah tersebut, seperti buku, jurnal, artikel dan lain sebagainya.

\subsection{Representasi Kasus}

Data kasus yang diperoleh dari catatan rekam medis disimpan menjadi case base. Kasus yang sudah terkumpul direpresentasikan ke dalam bentuk frame. Frame berisi relasi antara data pasien, penyakit yang diderita, faktor resiko dan gejalagejala yang menyertai kasus tersebut. Setiap kasus diberikan tingkat kepercayaan/keyakinan dari pakar terhadap hubungan data-data tersebut, sehingga dengan representasi ini dapat dibuat suatu model kasus untuk sistem CBR, dimana problem space adalah faktor resiko dan gejala-gejala penyakit serta solution space adalah nama penyakit.

Setiap faktor resiko dan gejala memiliki bobot yang menunjukan tingkat kepentingan terhadap penyakit yang diderita pasien. Nilai bobot antara 1 sampai 10, semakin besar nilai bobot, maka semangkin penting faktor resiko atau gejala tersebut untuk menentukan penyakit pasien. Tingkat kepercayaan menunjukan kepastian diagnosa dari pakar berdasarkan faktor resiko dan gejala yang dialami pasien.

\subsection{Retrieval dan Similarity}

Retrieval merupakan inti dari CBR, yaitu proses menemukan kasus lama dalam case base yang paling dekat dengan kasus saat ini (kasus baru). Teknik retrieval yang paling sering diselidiki sejauh ini, adalah $k$-nearest neighbor, pohon keputusan dan turunannya. Teknik ini menggunakan similarity metric untuk menentukan ukuran kedekatan antar kasus. Pada penelitian ini, metode similaritas yang digunakan adalah simple matching coefficient dengan persamaan (1) (Tursina, 2012).

dimana :

$$
\operatorname{SMC}(X, Y)=\frac{M 11+M 00}{M 10+M 01+M 11+M 00}
$$


$\mathrm{X}=$ Kasus lama

$\mathrm{Y}=$ Kasus Baru

M11= Jumlah atribut dimana $X=1$ dan $Y=1$

$\mathrm{M} 10=$ Jumlah atribut dimana $X=1$ dan $Y=0$

M01 = Jumlah atribut dimana $X=0$ dan $Y=1$

$\mathrm{M} 00=$ Jumlah atribut dimana $\mathrm{X}=0$ dan $\mathrm{Y}=0$

Jika tingkat kemiripan antara kasus lama dengan kasus baru cukup tinggi maka kasus tersebut akan di-reuse dimana solusi kasus lama tersebut akan digunakan kembali sebagai solusi kasus baru.

\subsection{Revisi Kasus}

Revisi kasus merupakan bagian dari adaptasi sistem yang dilakukan oleh seorang pakar. Pakar akan merevisi nama penyakit beserta tingkat kepercayaan terhadap penyakit hasil diagnosa memiliki nilai similarity lebih kecil dari 0.8. Setelah kasus direvisi, selanjutnya kasus tersebut akan disimpan (retain) dan dijadikan sebagai basis kasus baru.

\subsection{Desain Sistem}

Desain sistem meliputi kegiatan perancangan dan konstruksi, baik desain yang berhubungan dengan alur sistem, pemrosesan sampai dengan rancangan antar muka (inteface) sistem yang akan bangun. Desain dalam membangun sistem CBR untuk mendiagnosa penyakit kardiovaskuler dengan metode simple matching coefficient ini terdiri dari desain arsitektur sistem, perancangan arus data (DFD), perancangan basis data dan perancangan antar muka.

\subsection{Implementasi Sistem}

Sistem dibagi menjadi 2 kategori berdasarkan jenis pemakai yaitu pakar dan paramedis. Masingmasing kategori pemakai mempunyai hak akses terhadap sistem yang dengan fasilitas yang berbedabeda. Admin/pakar memiliki hak akses untuk menambahkan pengguna baru pada sistem, memasukan data pengetahuan, memasukan dan merevisi kasus hasil diagnosa serta melakukan diagnosa. Sedangkan user dengan jenis Paramedis memiliki hak akses untuk memasukkan data pasien, mendiagnosa kasus baru serta menyimpan kasus baru.

\subsection{Pengujian Sistem}

Pengujian sistem dilakukan dengan tes diagnostik untuk mengukur kemampuan sistem dalam mendeteksi seseorang terkena penyakit atau tidak. Akobeng (2007), menjelaskan bahwa sensitivitas dan spesifisitas digunakan untuk mengetahui akurasi dari tes diagnostik. Nilai prediktif dapat digunakan untuk memperkirakan probabilitas penyakit, namun nilai prediksi positif dan nilai prediksi negatif bervariasi sesuai dengan prevalensi penyakit.
Analisis dilakukan dengan menggunakan 4 parameter yaitu TP, FP, TN dan FN. Selanjutnya parameter tersebut digunakan dalam menghitung sensitivitas (sensitivity), spesifisitas (specificity), nilai prediksi positif (PPV) dan nilai prediksi negatif (NPV). Perhitungan nilai-nilai tersebut menggunakan persamaan (2), (3), (4), (5) (Tomar $\mathrm{dkk}, 2012)$.

$$
\begin{aligned}
& \text { Sensitivity }=\left[\frac{T P}{T P+F N}\right] \times 100 \% \\
& \text { Specificity }=\left[\frac{T N}{T N+F P}\right] \times 100 \% \\
& P P V=\left[\frac{T P}{T P+F P}\right] \times 100 \% \\
& N P V=\left[\frac{T N}{T N+F N}\right] \times 100 \%
\end{aligned}
$$

Menurut Han \& Kamber (2006), confusion matrix adalah cara yang berguna untuk menganalisis seberapa baik sistem mengenali tuple dari kelas yang berbeda. TP dan TN memberikan informasi ketika sistem benar, sedangkan FP dan FN memberitahu ketika sistem salah. Sensitivitas dan spesifisitas dapat digunakan untuk mengklasifikasikan akurasi. Sensitivitas dapat ditunjuk sebagai true positives (recognition) rate (proporsi dari tuple positif yang diidentifikasi dengan benar). Sedangakan spesifisitas adalah true negatives rate (proporsi tuple negatif yang diidentifikasi secara benar). Fungsi sensitivitas dan spesifisitas dapat menunjukkan tingkat akurasi menggunakan persamaan (6) dan ukuran tingkat kesalahan sistem menggunakan persamaan (7).

$$
\begin{aligned}
& \text { Accuracy }=S V \frac{P}{(P+N)}+S F \frac{N}{(P+N)} \\
& \text { Error rate }=\frac{F P+F N}{(P+N)} \times 100 \%
\end{aligned}
$$

dimana:

$$
\begin{aligned}
& \mathrm{SV}: \text { Nilai sensitivitas } \\
& \mathrm{SF} \text { : Nilai spesifisitas } \\
& \mathrm{P} \text { : Jumlah total kasus dengan hasil positif } \\
& \mathrm{N}
\end{aligned}
$$

\section{HASIL DAN PEMBAHASAN}

\subsection{Proses Pengisian Basis Kasus}

Terdapat 126 kasus dengan 74 gejala dan 9 jenis faktor resiko yang mengalami penyakit golongan I21 (Acute Myocardial Infarction). Data yang digunakan merupakan kumpulan data rekam medis pasien rawat inap penyakit kardiovaskuler RSUP. Sardjito Yogyakarta. Sebelum melakukan pengisian basis kasus, user terlebih dahulu memasukan data pasien, data penyakit, data gejala dan data faktor resiko kedalam sistem.

\subsection{Proses Diagnosa}

Sistem melakukan proses diagnosa dengan teknik anamnesis yaitu, dengan memperhatikan faktor resiko dan gejala yang tampak pada pasien. Proses diagnosa diawali dengan memilih data pasien. Selanjutnya memasukkan data gejala dan 
data faktor resiko yang dialami seorang pasien, kemudian sistem melakukan proses retrieve dan menghitung tingkat kemiripan menggunakan metode simple matching coefficient. Alur proses yang terjadi pada saat sistem melakukan diagnosa di sajikan pada Gambar 2.

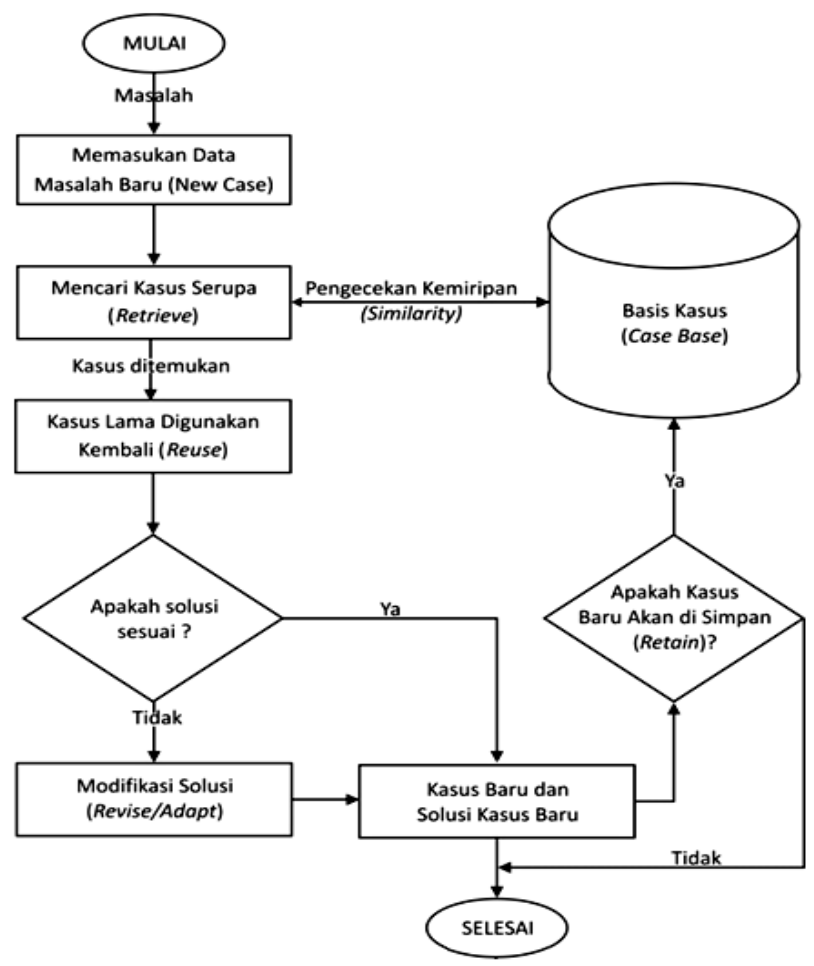

Gambar 2. Alur Diagnosa

Setiap kasus baru akan dihitung tingkat kemiripanya dengan kasus lama berdasarkan kemunculan gejala dan faktor resiko. Perhitungan similaritas dilakukan pada setiap kasus yang memiliki kesamaan fitur dengan kasus baru, kemudian memilih kasus dengan kemiripan tertinggi sebagai solusi. Berikut contoh perhitungan similaritas antara case base dan target case (data kasus baru) secara manual.

Tabel 1. Sampel basis kasus

\begin{tabular}{|c|c|c|c|c|}
\hline \multirow[t]{2}{*}{ No } & \multirow[t]{2}{*}{ Data Kasus } & \multicolumn{2}{|c|}{$\begin{array}{l}\text { Source Case / } \\
\text { Case Base (S) }\end{array}$} & \multirow{2}{*}{$\begin{array}{c}\text { Target Case / } \\
\text { Kasus Baru } \\
\text { (T) }\end{array}$} \\
\hline & & K001 & K002 & \\
\hline $\mathbf{A}$ & Data Pasien & Nilai & Nilai & Nilai \\
\hline 1 & Umur & 50 & 60 & 53 \\
\hline 2 & Jenis Kelamin & $\mathrm{L}$ & $\mathrm{P}$ & $\mathrm{L}$ \\
\hline $\mathbf{B}$ & \multicolumn{4}{|l|}{ Faktor Resiko } \\
\hline 1 & R001 & 1 & 1 & 1 \\
\hline 2 & R002 & 0 & 1 & 0 \\
\hline 3 & R003 & 0 & 1 & 0 \\
\hline 4 & R004 & 1 & 1 & 0 \\
\hline 5 & R005 & 1 & 1 & 1 \\
\hline 6 & R006 & 1 & 1 & 1 \\
\hline 7 & R007 & 1 & 0 & 1 \\
\hline C & \multicolumn{4}{|l|}{ Gejala } \\
\hline 1 & G001 & 1 & 1 & 1 \\
\hline 2 & G002 & 0 & 1 & 1 \\
\hline 3 & G003 & 1 & 0 & 1 \\
\hline 4 & G004 & 0 & 1 & 0 \\
\hline 5 & G005 & 1 & 1 & 1 \\
\hline 6 & G006 & 1 & 0 & 1 \\
\hline \multicolumn{2}{|c|}{ Penyakit } & P001 & $\mathrm{P} 002$ & \multirow{2}{*}{$?$} \\
\hline \multicolumn{2}{|c|}{ Solusi } & S001 & S002 & \\
\hline
\end{tabular}


Proses perhitungan similaritas contoh kasus yang disajikan pada Tabel 1 adalah sebagai berikut:

1. Kemiripan taget case dengan source case (K001)

$$
\begin{aligned}
\operatorname{SMC}(X, Y) & =\frac{6+0}{4+3+6+0} \\
& =\frac{7}{13}=0.46
\end{aligned}
$$

2. Kemiripan taget case dengan source case (K002)

$$
\begin{aligned}
\operatorname{SMC}(X, Y) & =\frac{8+3}{1+1+8+3} \\
& =\frac{11}{13}=0.85
\end{aligned}
$$

Berdasarkan hasil perhitungan similaritas kasus baru terhadap kasus lama yang terdapat pada basis kasus (K001 dan K002), nilai kemiripan pada kasus $\mathrm{K} 002=0.85$, lebih besar dari pada kasus K001=0.46. Sehingga dapat disimpulkan bahwa kasus K002 adalah kasus yang paling mirip dengan kasus baru.

Hasil pengembangan aplikasi, proses diagnosa meliputi proses input kondisi pasien, pemeriksaan/pencarian kasus terdahulu yang mirip dengan kasus baru (retrieve), menghitung tingkat kemiripan (similaritas) dan menyimpulkan hasil diagnosa berdasarkan nilai kemiripan paling tinggi.
Proses pada form diagnosa dimulai dengan memilih menu diagnosa. Pada saat muncul form diagnosa sistem akan secara otomatis memberikan nomor kasus berdasarkan nomor urut kasus yang telah tersimpan dalam basis data. Selanjutnya user (baik pakar maupun paramedis) harus memilih data pasien.

Pencarian data pasien dapat dilakukan berdasarkan kode pasien, nomor rekam medis dan nama pasien. Jika pasien belum tersimpan dalam basis data, maka user dapat melakukan penambahan data pasien baru dengang mengklik tombol tambah. Saat data pasien ditemukan, sistem akan mengambil kode pasien, jenis kelamin dan tangga lahir. Tanggal lahir akan dikonversi menjadi usia (umur pasien) dengan menghitung berdasarkan tanggal sekarang.

Data yang perlu dimasukan oleh user adalah data faktor resiko dan data gejala yang dimiliki pasien (Gambar 3). Input data faktor resiko dapat dilakukan dengan memilih daftar faktor resiko pada combobox atau dapat juga dilakukan dengan mencari data dengan meng-click tombol cari.. Jika terdapat data faktor resiko baru, user dapat menambahkan faktor resiko baru tersebut dengan meng-click tombol tambah pada form cari data faktor resiko.

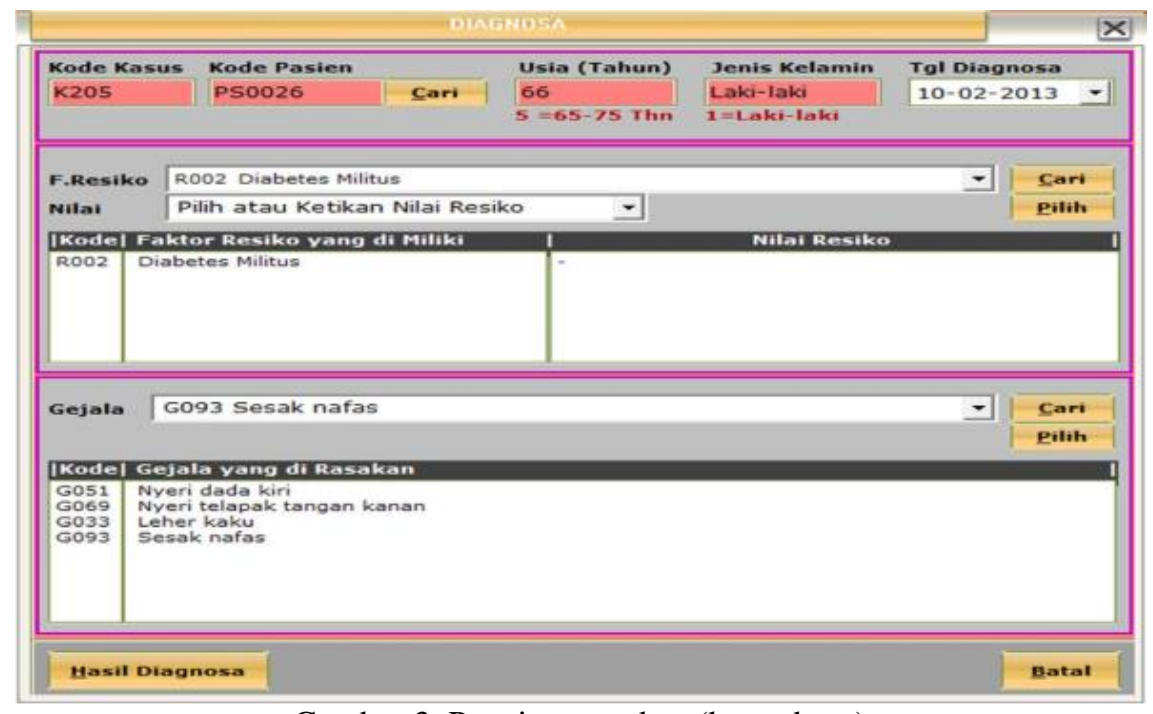

Gambar 3. Penginputan data (kasus baru)

Setelah faktor resiko terpilih, untuk beberapa faktor resiko user perlu memasukan nilai faktor resiko tersebut, misalnya untuk faktor keturunan user perlu memasukan berapa banyak faktor resiko ini ditemukan pada orang tua pasien dan penyakit apa saja yang di alami. Sebagai contoh seorang pasien memiliki orang tua yang mengalami penyakit Stroke dan sakit jantung, sehingga user akan mengisi nilai faktor resiko dengan $2 \mathrm{FH} /$ Factor History (Stroke, Sakit Jantung). Selanjutnya click tombol Pilih untuk memasukan data faktor resiko tersebut kedalam listbox.
Proses memasukkan data gejala pasien hampir sama dengan faktor resiko, perbedaanya adalah pada pemilihan gejala tidak ada nilai yang perlu di tambahkan, cukup dengan memilih gejala yang dirasakan pasien. Setelah semua data dimasukan, selanjutnya user harus meng-click tombol Hasil Diagnosa untuk mengetahui hasil diagnosa pasien tersebut.

Setelah proses perhitungan similaritas masingmasing kasus yang memiliki kesamaan dengan kasus baru, langkah selanjutnya adalah mengurutkan nilai similaritas dari nilai tertinggi ke nilai terrendah. Kasus dengan nilai similaritas tertinggi adalah kasus 
yang paling mirip dengan kasus baru, kemudian solusi dari kasus tersebut akan direkomendasikan sebagai solusi kasus baru tersebut. Sehingga hasil diagnosa ditampilkan seperti pada Gambar 4. Hasil diagnosa ini dapat dicetak pada media kertas (print out).

Selanjutnya user dapat menyimpan hasil diagnosa tersebut kedalam basis kasus dengan ketentuan tertentu. Jika nilai kemiripan mencapai nilai threshold yaitu minimal 0,8 atau $80 \%$ maka kasus tersebut akan disimpan dengan status 1 yang berarti dapat diikutkan dalam proses diagnosa kasus berikutnya. Jika nilai similaritas kurang dari 0,8 maka kasus tersebut akan disimpan dengan status 0 , artinya kasus tersebut perlu mendapatkan revisi dari pakar dan tidak akan gunakan dalam proses diagnosa kasus berikutnya sebelum mendapat revisi dari pakar. Penyimpanan kasus dengan status 1 hanya dapat dilakukan user dengan hak akses sebagai pakar.

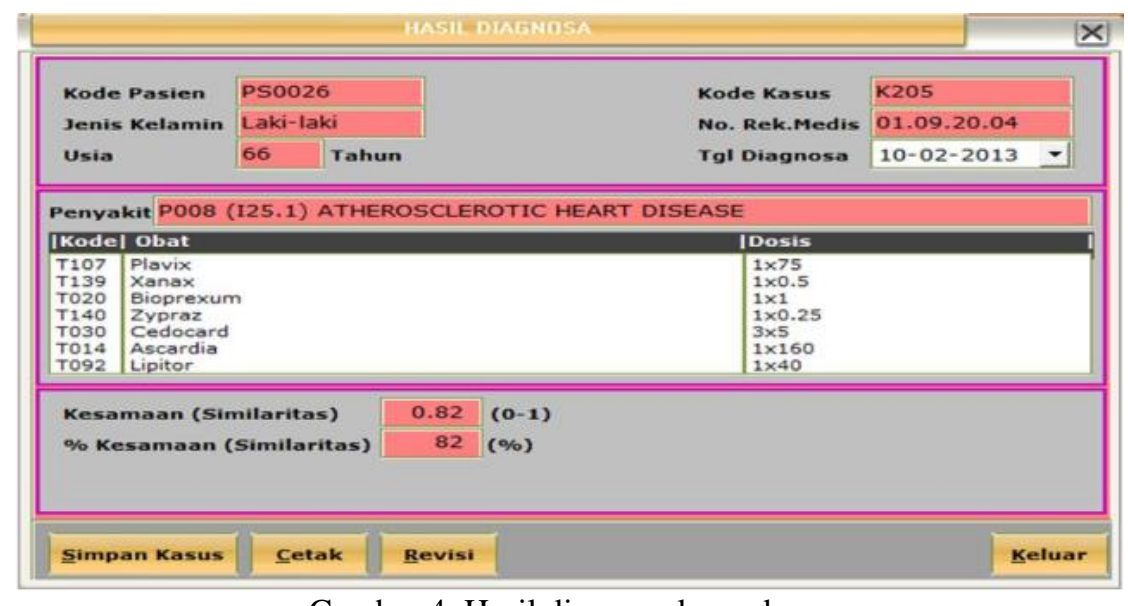

Gambar 4. Hasil diagnosa kasus baru

\subsection{Proses Revisi Kasus}

Proses revisi kasus perlu dilakukan apabila sistem tidak mampu mendiagnosa penyakit dengan benar. Sistem dianggap tidak berhasil melakukan diagnosa apabila nilai similaritas kurang dari 0.8 (80\%). Proses revisi hanya dapat dilakukan user dengan hak akses sebagai pakar.

\subsection{Proses Pengujian Sistem}

Proses pengujian sistem dilakukan dengan menggunakan sampel data rekam medis acak sebanyak 30\% dari 126 kasus dan ditambahkan 10 kasus penyakit I.50. Proses pengujian di bagi dalam 4 tahap yaitu $10 \%$ sampel di uji sebanyak 1 kali, $10 \%$ di uji sebanyak 3 kali dan 10\% diuji sebanyak 5 kali. Sedangkan sampel jenis penyakit yang berbeda (I.50) di lakukan sebanyak 3 kali. Hasil pengujian masing-masing sampel di ambil dari rata-rata hasil pengujian tiap sampel. Nilai kepercayaan pakar terhadap sebuah kasus yang terdapat dalam data rekam medis adalah $100 \%$, karena sudah melalui observasi dan pengujian secara menyeluruh. Hasil pengujian ditampilkan dalam tabel confusion matrix berdasarkan nilai similaritas hasil pengujian sistem, seperti terlihat pada Tabel 2.

Tabel 2. Confusion matrix hasil pengujian

\begin{tabular}{l|ccc}
\hline \multirow{2}{*}{} & \multicolumn{3}{|c}{ Data uji penyakit } \\
\cline { 2 - 4 } I.21 & I.50 & Total Kasus \\
\hline \multirow{2}{*}{ Negatif } & $33(\mathrm{TP})$ & $1(\mathrm{FN})$ & $34(\mathrm{P})$ \\
& $5(\mathrm{FP})$ & $9(\mathrm{TN})$ & $14(\mathrm{~N})$ \\
\hline Total Kasus & 38 Kasus & 10 Kasus & $\mathbf{4 8}(\mathbf{P}+\mathbf{N})$ \\
\hline
\end{tabular}

Berdasarkan confusion matrix dapat dihitung tingkat sensitivitas, spesifisitas, PPV, NPV, akurasi dan error rate menggunakan persamaan (2), (3), (4), (5), (6) dan persamaan (7). Hasil perhitungan menunjukan nilai sensitifitas $97,06 \%$, spesifisitas 64,29\%, PPV 86,84\%, NPV 90,00\%, akurasi $87,50 \%$ dengan tingkat kesalahan (error rate) sebesar $12,50 \%$. Berdasarkan perhitungan hasil pengujian dapat disimpulkan bahwa sistem yang dikembangkan memiliki kemampuan yang cukup tinggi dalam mengenali/identifikasi (sensitifitas) jenis penyakit cardiovascular (I.21), serta memiliki kemampuan yang baik dalam membedakan penyakit selain I.21 (spesifisitas). Sistem mampu melakukan diagnosa terhadap penyakit I.21 dengan benar (PPV) dan memiliki kemampuan yang baik untuk mengenali penyakit selain I.21 (NPV). Secara keseluruhan dapat disimpulkan bahwa sistem yang di kembangan memiliki tingkat akurasi yang cukup baik dalam melakukan diagnosa. Tingkat kemungkinan terjadi kesalahan dalam diagnosa masih cukup tinggi yaitu diatas $10 \%$.

\section{KESIMPULAN}

Berdasarkan hasil pengujian sistem casebased reasoning untuk mendiagnosa penyakit kardiovaskuler dapat ditarik beberapa kesimpulan sebagai berikut:

1. Sistem case-based reasoning dengan menggunakan metode simple matching coefficient dapat diimplementasikan untuk melakukan diagnosa awal penyakit 
cardiovascular berdasarkan kondisi (gejala dan faktor resiko) seorang pasien.

2. Sistem memberikan diagnosa penyakit berdasarkan kemiripan antara kasus lama dan kasus baru. Diagnosa dianggap benar jika nilai similarity $\geq 0.8$.

3. Hasil pengujian sistem menunjukkan nilai sensitivitas dan spesifisitas masing-masing adalah 97,06\% dan 64,29\%. Nilai PPV 86,84\% dan NPV 90,00\%, dengan tingkat akurasi sebesar $87,50 \%$ serta tingkat kesalahan (error rate) sebesar $12,50 \%$.

\section{Daftar Pustaka}

PAL, K. S. \& SHIU, K.C.S. 2004. Foundations of Soft Case-based Reasoning. A John Wiley \& Sons, Inc., New Jersey.

FEBRIANTY, D., DEWANTO, R.A. \& ARADEA. 2007. Analisis Jaringan Syaraf Tiruan RPROP Untuk Mengenali Pola Elektrokardiografi Dalam Mendeteksi Penyakit Jantung Koroner. Seminar Nasional Aplikasi Teknologi Informasi 2007, ISSN: 1907-5022.

EFFENDY, N., SUBAGJA, \& FAISAL, A. 2008. Prediksi Penyakit Jantung Koroner (PJK) Berdasarkan Faktor Risiko Menggunakan Jaringan Syaraf Tiruan Backpropagation. Seminar Nasional Aplikasi Teknologi Informasi 2008, ISSN: 1907-5022.

ABBAS, M.A.E., 2012. Anticipating of Cardiovascular Heart Diseases Using Computer Based Poly Trees Model. International Journal of Computer Applications (0975 8887), Vol 59 No.13.

SHEKAR, K.C., KANTH, K.R. \& KANTH, K.S. 2012. Impropved Algorithm for Prediction of Heart Disease Using Case Base Reasoning Technique on Non-Binary Datasets. International Journal of Research in Computer and Communication Technology (IJRCCT), Vol 1, Issue 7, ISSN 2278-5841.

SALEM, A.B.M., ROUSHDY, M. \& HODHOD, R.A. 2005. A Case Based Expert System for Supporting Diagnosis of Heart Diseases. AIML Journal, vol. 5, no. 1, pp 33-39.

TOMAR, P.P.S., SINGH, R., SAXENA, P.K. \& SHARMA, B.K. 2012. A Medical Multimedia Based DSS for Heart Diseases Diagnosis and Training. Canadian Journal on Biomedical Engineering \& Technolog, Vol. 3 No. 2.

TURSINA. 2012. Case-Based Reasoning untuk Diagnosa Penyakit Respirologi Anak Menggunakan Similaritas Simple Mathcing
Coefficient. Jurnal ELKHA, Vol 4, No 1, Halaman 17-22.

CAMPOS, J., MAITE, L. \& MARC, E. 2010. A Case-Based Reasoning Approach for Norm Adaptation. Hybrid Artificial Intelligence Systems, Vol 6077, ISBN 978-3-64213802-7, Halaman 168-176.

AKOBENG, A.K. 2007. Understanding diagnostic tests 1:sensitivity, specificity and predictive values. Acta Pædiatrica, Vol. 96 No. 3, ISSN:1651-2227, Halaman 338-341.

HAN, J. \& KAMBER, M. 2006. Data Mining: Concepts and Techniques Second Edition. Morgan Kauffman. ISBN 978-92-4156437-3, San Fransisco. 